$$
\begin{gathered}
\text { 울산지역 노인의 구강건강이 노인의 전 반적 건강상태와 } \\
\text { 사회활동에 미치는 영향 } \\
\text { 최유진 }{ }^{1 \neq}, \text { 권수진 }^{2}, \text { 류황건 }{ }^{3}
\end{gathered}
$$

\title{
The Effect of Geriatric Oral Health on Health Status and Social Activity in Ulsan Province
}

\author{
Yu-Jin Choi ${ }^{1} \ddagger$, Su-Jin Kwon ${ }^{2}$, Hwang-Gun Ryu ${ }^{3}$ \\ ${ }^{1}$ Youngsan University, ${ }^{2}$ Busan Institute of science \& Technology, ${ }^{3}$ Kosin University
}

\begin{abstract}
$<$ Abstract $>$
This study is to observe the effect of oral health of elderly on overall health status and social activity to provide basic data for oral health improvement program for the elderly and development of related policies. The survey was conducted from July 25th to July 29th, 2011, and used 145 copies for this research analysis. As a result of correlation analysis, it is observed that all of 4 sub factors of Geriatric Oral Health Assessment Index have significant static correlation with overall health status of elderly and social activity also has significant static correlation with oral health. As a result of regression analysis, the functional limitation out of sub factors showed significant positive effect on health status and psychological effect has significant positive effect on social activity. Based on the above result, it is observed that, at the time of rapidly entering to an aging society, the life quality related to oral health of elderly which is part of overall health and overall health status and social activity areas that are recognized by the elderly have significant correlation. And, it is important to understand the factors of oral health affecting health status and social activity. Based on the result of this study, more researches on the development of oral health program and development of assessment tool that can be easily employed should be made.
\end{abstract}

Key Words : Elderly, Geriatric Oral Health Assessment Index, Overall Health Status, Social Activity 


\section{I. 서 론}

1. 연구의 배경 및 목적

우리나라는 최근 급속한 경제 성장과 의료기술 의 발달로 인하여 평균수명이 늘어나고 저 출산 경향이 지속되면서 노인인구의 비율이 급증하고 있다[1]. 2008년 통계청 자료에 따르면 우리나라 전체 인구 중에 65 세 이상 노인 인구가 $7.4 \%$ 를 차 지하며, 2018년에는 $14.4 \%$ 에 달하는 고령사회로, 2020 년에는 $20 \%$ 가 넘는 초고령화 사회가 될 것이 라고 전망하고 있다. 노년기에 행복해지기 위해서 는 활동을 계속 유지해야 한다는 활동이론이 있다. 이에 따르면 노년기에도 사람들은 중년기와 마찬 가지로 활동 할 것을 기대하며 여러 활동에 적극 참여함으로써 행복을 느낀다는 것이다[2]. 사회활 동 참여는 새롭고 다양한 경험의 기회를 제공하고, 적극적으로 상호작용할 수 있게 하는 수단을 제공 하며, 또한 참여를 통하여 노인의 건강이 증진 되 고[3], 사회적 통합을 가져오며 자아 존중감을 높 여주고[4], 궁극적으로 심리적 안정과 삶의 만족도 가 향상된다고 강조하고 있다[5]. 노인의 사회참여 의 범위가 클수록 그리고 이전에 해왔던 사회 활 동유형과 차이가 없을수록 사회활동에 참여함으로 얻게 되는 전반적 삶의 만족도가 향상 된다는 것 이다. 이와 같이 노인의 사회활동에 대한 연구는 노인의 삶의 질 혹은 행복감과도 밀접한 관계가 있어 다가올 고령사회 노인연구에 매우 중요한 과 제임을 알 수 있다[6]. 우리나라에서는 1995년 국 민건강증진법이 제정되면서 생활습관개선을 통한 국민건강증진사업을 시작하여 전국 보건소를 거점 으로 건강증진사업이 활발하게 진행되고 있다. 구 강보건사업도 금연, 절주, 운동, 영양 등과 더불어 중요한 건강증진 사업의 하나로 선정되어 정책적 으로 치면 열구전색사업, 수돗물 불소농도조정사 업, 초등학교구강보건실 개소 등 많은 사업이 추진
되고 있다. 이는 구강보건이 전신건강에서 차지하 는 비중이 커지고 있기 때문이라고 볼 수 있다. 그 러나 아직까지 전신건강에 비하여 구강건강을 소 홀히 생각하고 자신의 구강상태를 노화의 결과로 받아들이는 사람들이 많아 선진국 수준으로의 인 식 개선은 미흡한 실정이다[7].

노인을 대상으로 이와 관련된 그 간의 연구를 살펴보면 주로 노인의 구강건강과 관련한 삶의 질 평가 지수에 관한 연구 신선정(2011)[8], 장선희 (2011)[9], 조영식(2011)[10]의 연구가 있었고, 노인 구강건강 영향지수의 영향요인에 관한 연구로 박 정란(2011)[11], 이명선(2007)[12]의 연구가 있으며, 전신건강과 구강건강과의 관련성 연구 박영애 (2006)[13]에 그쳤고, 최근 확장된 연구로 노인의 사회경제적 위치와 구강건강관련 삶의 질과의 상 관성에 관한 연구로 이민선(2011)[14]의 연구가 있 었지만 노인의 삶의 질 평가지수를 사용해 전반적 건강상태 및 사회활동까지 연관 지어 살펴본 연구 는 전무한 실정이다. 이에 본 연구에서는 노인들의 건강에 직접적인 영향을 미치는 구강건강과 관련 한 삶의 질 지표인 노인구강건강평가지수(Geriatric Oral Health Assessment Index, GOHAI)를 사용해 구강건강이 전반적인 건강상태와 사회활동에 미치 는 영향을 분석하여 노인의 구강건강증진 프로그 램 및 이에 관련된 정책개발을 위한 기초자료로 활용하고자 실시하였다.

\section{ㅍ. 연구방법}

1. 연구도구

1) 노인구강건강평가지수(Geriatric Oral Health Assessment Index, GOHAI)

Atchison과 Dolan[15]이 개발한 노인구강건강평 가지수를 이용하여 노인들의 구강건강을 평가하였 
다. GOHAI는 노인의 구강건강 평가를 기능적 제 한, 동통이나 불편감, 심리적 영향, 행동영향의 4 개 의 하위요인으로 나누어 총 12 개의 문항을 사용하 였다.

\section{2) 전반적 건강상태}

전반적 건강상태는 전예슬(2009)[16]이 선행 연 구한 것을 수정하여 사용하였다. 전반적 건강상태 는 신체적 건강의 자기평가적 차원으로 건강 상태 에 대한 개인의 지각과 평가를 의미한다. 자기 평 가적 차원에서의 신체적 건강은 본인의 연령을 고 려한 건강평가, 동년배와의 비교한 건강평가. 개인 의 과거의 건강수준에 대비한 현재의 건강평가등 총 4 가지 문항을 사용하였다.

\section{3) 사회활동}

사회활동의 척도는 Weiss의 사회참여척도를 윤 명희(2005)[17]가 선행 연구한 것을 수정하여 11개 문항을 사용하였으며, 전혀 아니다(1점)에서 항상 그렇다(5점)로 점수가 높을수록 사회활동 참여 정 도가 높다.

\section{2. 연구설계}

본 연구의 대상자는 울산광역시에 등록된 노인 복지기관 중 조사에 협조를 얻은 2 개 기관을 선정
하였으며 연구자와 훈련된 조사요원이 직접 방문 하여 설문조사 취지를 설명한 후 이에 동의한 노 인 154명을 대상으로 하였다. 조사기간은 2011년 7 월 25일부터 2011년 7월 29일까지 5일간 진행되었 고, 이 중 응답내용이 불성실한 9부를 제외한 145 부가 최종분석에 사용하였다.

3. 연구모형 및 가설

본 연구에서는 다음의 내용을 중심으로 가설을 설정하여 제시하였다.

가설1. 기능적 제한은 노인의 전반적 건강상태에 영향을 미칠 것이다.

가설2. 동통이나 불편감은 노인의 전반적 건강상태에 영 향을 미칠 것이다.

가설3. 심리적 영향은 노인의 전반적 건강상태에 영향을 미칠 것이다.

가설4. 행동영향은 노인의 전반적 건강상태에 영향을 미 칠 것이다.

가설5. 기능적 제한은 노인의 사회활동에 영향을 미칠 것 이다.

가설6. 동통이나 불편감은 노인의 사회활동에 영향을 미 칠 것이다.

가설7. 심리적 영향은 노인의 사회활동에 영향을 미칠 것 이다.

가설8. 행동영향은 노인의 사회활동에 영향을 미칠 것이 다.

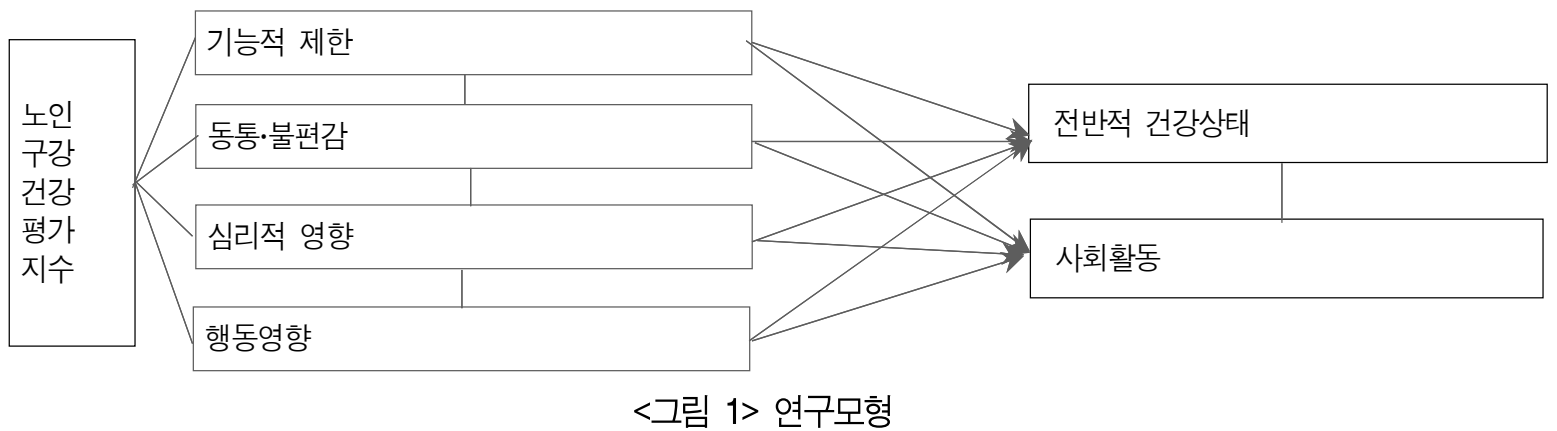




\section{4. 자료분석}

설문을 통해 수집된 자료는 SPSS 15.0 통계프로 그램을 이용하여 분석하였다. 통계에 사용한 기법 들은 조사대상의 인구 통계학적 분포를 알아보기 위하여 빈도분석을 실시하고, Cronbach의 a계수 를 구하여 조사도구의 신뢰도 분석을 실시하였으 며 조사도구의 신뢰도는 건강상태 .759 , 사회활동 .874 , 구강건강지수 .677 로 신뢰성이 확보되었다.

연구모형에 따른 분석을 실시하기에 앞서 우선 변인 간 관계를 상관분석을 실시하여 알아보았으 며, 변인간 영향관계를 회귀분석을 실시하여 알아 보았다.

\section{III. 연구결과}

\section{1. 표본의 일반적 특성}

조사대상 노인의 일반적 사항에 대해 빈도분석 을 시행한 결과는 <표 1>과 같다.

조사대상자의 성별은 남자가 56 명 $(38.6 \%)$, 여자 가 89 명 $(61.4 \%)$ 로 여자가 더 많았고, 연령은 75 세 이하가 72명(49.7\%), 76세 이상이 73명(50.3\%)로 비 슷한 수준이었으며, 학력은 초등학교 졸이 59명 $(40.7 \%)$ 로 가장 많았으며, 동거인은 혼자 산다가 55 명 $37.9 \%)$, 부부가 같이 산다가 54 명 $(37.2 \%)$ 으로 비슷한 수준이었으며 자녀와 같이 산다가 36 명 $(24.8 \%)$ 로 나타났다.

직업은 없다는 응답이 143 명 $(98.6 \%)$ 로 대부분이 었고, 소득원은 자녀라는 응답이 81 명 $(55.9 \%)$ 로 본 인 또는 배우자라는 응답 49 명(33.8\%)과 기초수급 자라는 응답 15 명 $(10.3 \%)$ 에 비해 높게 나타났다. 소득정도는 보통이라는 응답이 $52.4 \%$ 로 가장 많았
으나, 넉넉하다는 응답(11.7\%)보다 부족하다는 응 답(35.9\%)이 더 많았다.

<표 1> 조사대상자의 일반적 사항

\begin{tabular}{|c|c|c|c|}
\hline & 구 분 & 빈도 & 비율(\%) \\
\hline \multirow{2}{*}{ 성별 } & 남 & 56 & 38.6 \\
\hline & 여 & 89 & 61.4 \\
\hline \multirow{2}{*}{ 연령 } & 75세 이하 & 72 & 49.7 \\
\hline & 76세 이상 & 73 & 50.3 \\
\hline \multirow{4}{*}{ 학력 } & 무학 & 30 & 20.7 \\
\hline & 초졸 & 59 & 40.7 \\
\hline & 중졸 & 34 & 23.4 \\
\hline & 고졸이상 & 22 & 15.2 \\
\hline \multirow{3}{*}{ 동거인 } & 혼자 & 55 & 37.9 \\
\hline & 부부 & 54 & 37.2 \\
\hline & 자녀 & 36 & 24.8 \\
\hline \multirow{2}{*}{ 직업 } & 있다 & 2 & 1.4 \\
\hline & 없다 & 143 & 98.6 \\
\hline \multirow{3}{*}{ 소득원 } & 본인 또는 배우자 & 49 & 33.8 \\
\hline & 자녀 & 81 & 55.9 \\
\hline & 국민기초수급자 & 15 & 10.3 \\
\hline \multirow{3}{*}{ 소득정도 } & 부족 & 52 & 35.9 \\
\hline & 보통 & 76 & 52.4 \\
\hline & 넉넉 & 17 & 11.7 \\
\hline 계 & & 145 & 100.0 \\
\hline
\end{tabular}

2. 일반적 특성에 따른 전반적 건강상태, 사회 활동 및 구강건강 비교

조사대상 노인의 일반적 사항에 따라 전반적 건 강상태, 사회활동, 구강건강이 차이를 보이는지 조 사한 결과는 <표 $2>$ 와 같다. 
<표 2> 일반적 사항에 따른 전반적 건강상태, 사회활동 및 구강건강 차이

\begin{tabular}{|c|c|c|c|c|}
\hline & 구 분 & 전반적 건강상태 & 사회활동 & 구강건강 \\
\hline \multirow{3}{*}{ 성별 } & 남 & $8.32(2.09)$ & $4.12(0.52)$ & $6.89(2.53)$ \\
\hline & 여 & $7.52(1.94)$ & $4.06(0.59)$ & $6.65(2.84)$ \\
\hline & $t$ & $2.32 *$ & .65 & .52 \\
\hline \multirow{3}{*}{ 연령 } & 75세 이하 & $8.11(2.02)$ & $4.09(0.55)$ & $6.76(2.89)$ \\
\hline & 76세 이상 & $7.55(2.01)$ & 4.08(0.57) & $6.73(0.56)$ \\
\hline & $t$ & 1.68 & 0.79 & 0.84 \\
\hline \multirow{5}{*}{ 학력 } & 무학 & $7.30(2.09) a$ & $3.88(0.61) a$ & $5.93(2.64)$ \\
\hline & 초졸 & $7.58(1.93) a b$ & $4.03(0.54) a b$ & $6.93(2.76)$ \\
\hline & 중졸 & $8.09(2.08) a b$ & $4.24(0.54) b$ & $6.71(2.98)$ \\
\hline & 고졸이상 & $8.82(1.84) b$ & $4.25(0.50) b$ & $7.41(2.13)$ \\
\hline & $\mathrm{F}$ & $3.04 *$ & $3.16 \star$ & 1.44 \\
\hline \multirow{4}{*}{ 동거인 } & 혼자 & $7.25(2.10) \mathrm{a}$ & $4.12(0.60)$ & $6.56(2.55)$ \\
\hline & 부부 & $8.30(2.04) b$ & $4.09(0.49)$ & $6.70(2.68)$ \\
\hline & 자녀 & $8.00(1.71) a b$ & $4.02(0.61)$ & $7.08(3.06)$ \\
\hline & $\mathrm{F}$ & $3.92 *$ & .39 & .40 \\
\hline \multirow{4}{*}{ 소득원 } & 본인 또는 배우자 & $8.00(2.04)$ & $4.12(0.51)$ & $6.76(2.78)$ \\
\hline & 자녀 & $7.84(1.98)$ & $4.01(0.58)$ & $6.81(2.76)$ \\
\hline & 국민기초수급자 & $7.20(2.24)$ & $4.35(0.56)$ & $6.33(2.38)$ \\
\hline & $\mathrm{F}$ & .90 & 2.37 & .20 \\
\hline \multirow{4}{*}{ 소득정도 } & 부족 & $7.38(2.38)$ & $4.20(0.61)$ & $6.75(3.05)$ \\
\hline & 보통 & $8.08(1.76)$ & $4.02(0.51)$ & $6.62(2.56)$ \\
\hline & 넉넉 & $8.06(1.89)$ & $4.02(0.60)$ & $7.29(2.39)$ \\
\hline & $\mathrm{F}$ & 1.96 & 1.74 & .43 \\
\hline 계 & & $7.83(2.03)$ & $4.08(0.56)$ & $6.74(2.72)$ \\
\hline
\end{tabular}

*건강상태는 3 12, 사회활동은 1 5, 구강건강은 0 12의 점수범위이며, 점수가 높을수록 건강과 구강건강상태가 양 호하며, 사회활동이 활발함.

*서로 다른 영문자는 Scheffe의 사후검증결과에서 유의한 차이로 나타남을 의미함.

일반적 사항에 따른 차이검증 결과, 성별에 따 라 건강상태의 차이를 보였으며, 남자(8.32)가 여자 (7.52)에 비해 건강상태가 좋은 것을 볼 수 있었다 $(\mathrm{p}<.05)$.

학력에 따라서는 전반적 건강상태와 사회활동 참여정도가 차이를 보였으며, 전반적 건강상태는 학력이 높을수록 건강상태가 좋은 것을 볼 수 있 었으며, 사후검증을 통해 고졸이상 집단(8.82)이 무 학(7.30)집단에 비해 전반적 건강상태가 좋은 것을
알 수 있었다( $\mathrm{p}<.05)$.

사회활동도 학력이 높을수록 좋은 것을 볼 수 있었으며, 사후검증을 통해 중졸(4.24)과 고졸 이상 집단(4.25)이 무학(3.88)집단에 비해 사회활동 정도 가 좋은 것을 알 수 있었다 $(\mathrm{p}<.05)$.

동거인에 따라서는 전반적 건강상태가 차이를 보였으며, 사후검증을 통해 부부가 같이 사는 노인 집단(8.30)이 혼자 사는 노인집단(7.25)에 비해 건강 상태가 좋은 것을 알 수 있었다( $\mathrm{p}<.05)$. 
3. 전반적 건강상태, 사회활동, 구강건강의 관계

조사대상자의 전반적 건강상태, 사회활동, 구강 건강의 상관관계를 알아보기 위하여 피어슨 상관 분석을 시행하였으며 결과는 <표 3>과 같다.

상관분석을 통해 전반적 건강상태, 사회활동, 구 강건강의 관계를 알아본 결과에서 전반적 건강상 태는 사회활동 $(\mathrm{r}=.19, \mathrm{p}<.05)$ 과 유의한 정적인 상관 을 가지는 것으로 나타나 전반적 건강상태가 양호 한 노인이 사회활동도 활발하게 참여하고 있다는 것을 알 수 있었다. 전반적 건강상태는 구강건강 $($ 계) $(\mathrm{r}=.33, \mathrm{p}<.01)$ 과 유의한 정적인 상관을 가지는 것으로 나타나 구강건강이 노인의 전반적 건강상 태와 밀접한 관계가 있음을 알 수 있었으며, 전반 적 건강상태는 구강건강의 하위요인인 기능적 제 한, 동통·불편감, 심리적 영향, 행동영향 모두와 유
의한 정적인 상관 $(\mathrm{r}=.18 \sim 32, \mathrm{p}<.05)$ 을 가지고 있었 다.

사회활동은 구강건강(계) $(\mathrm{r}=.30, \mathrm{p}<.01)$ 과 유의한 정적인 상관을 가지는 것으로 나타나 구강건강이 양호한 노인이 사회활동이 활발함을 볼 수 있었고, 사회활동은 구강건강의 하위요인인 기능적 제한, 동통·불편감, 심리적 영향과 유의한 정적인 상관 $(\mathrm{r}=.15 \sim 28, \mathrm{p}<.05)$ 을 가지고 있었다.

4. 구강건강이 전반적 건강상태에 미치는 영향

구강건강이 노인의 전반적 건강상태에 미치는 영향을 알아보기 위하여 구강건강의 4 가지 하위요 인을 독립변인으로 투입하여 회귀분석을 시행하였 으며 결과는 <표 $4>$ 와 같다.

<표 3> 전반적 건강상태, 사회활동, 구강건강의 관계

\begin{tabular}{|c|c|c|c|c|c|c|c|}
\hline & $\begin{array}{c}\text { 전반적 } \\
\text { 건강상태 }\end{array}$ & 사회활동 & 기능적제한 & $\begin{array}{c}\text { 동통 } \\
\text { ·불편감 } \\
\end{array}$ & 심리적 영향 & 행동영향 & $\begin{array}{c}\text { 구강건강 } \\
\text { (계) }\end{array}$ \\
\hline 건강상태 & 1.00 & & & & & & \\
\hline 사회활동 & $.19 *$ & 1.00 & & & & & \\
\hline 기능적제한 & $.32 * *$ & $.20 *$ & 1.00 & & & & \\
\hline 동통·불편감 & $.18 *$ & $.21 * *$ & $.26 * *$ & 1.00 & & & \\
\hline 심리적 영향 & $24 * *$ & $.28 * *$ & $.31 * *$ & $.42 * *$ & 1.00 & & \\
\hline 행동영향 & $.18 *$ & .15 & $.27 * *$ & $.35 * *$ & $.53 * *$ & 1.00 & \\
\hline 구강건강(계) & $33 * *$ & $.30 * \star$ & $.70 * *$ & $.65 * *$ & $.78 * *$ & $.74 * *$ & 1.00 \\
\hline
\end{tabular}

$* p<.05 * * p<.01$

<표 4> 구강건강의 하위요인이 건강상태에 미치는 영향

\begin{tabular}{lccccc}
\hline \multicolumn{1}{c}{ 독립변인 } & 회귀계수 & 표준오차 & 표준화계수 & $\mathrm{t}$ 값 & $\mathrm{p}$ 값 \\
\hline \hline (절 편) & 6.42 & .50 & & 12.93 & .000 \\
기능적제한 & .46 & .15 & .26 & 3.13 & .002 \\
동통불편감 & .13 & .24 & .05 & .53 & .598 \\
심리적 영향 & .28 & .21 & .13 & 1.30 & .195 \\
행동영향 & .06 & .21 & .03 & .29 & .773 \\
\hline
\end{tabular}

$\mathrm{F}(4,140)=5.224, \mathrm{p}=.001, \mathrm{R} 2=.13$

*구강건강의 하위요인은 점수가 높을 수록 구강건강상태가 양호함을 의미함 
<표 5> 구강건강의 하위요인이 사회활동에 미치는 영향

\begin{tabular}{lccccc}
\hline \multicolumn{1}{c}{ 독립변인 } & 회귀계수 & 표준오차 & 표준화계수 & $\mathrm{t}$ 값 & $\mathrm{p}$ 값 \\
\hline \hline (절 편) & 3.68 & .14 & & 26.37 & .000 \\
기능적제한 & .06 & .04 & .12 & 1.37 & .174 \\
동통불편감 & .08 & .07 & .11 & 1.17 & .243 \\
심리적 영향 & .13 & .06 & .22 & 2.16 & .032 \\
행동영향 & -.02 & .06 & -.03 & -.33 & .745 \\
\hline
\end{tabular}

$\mathrm{F}(4,140)=3.994, \mathrm{p}=.004, \mathrm{R} 2=.10$

*구강건강의 하위요인은 점수가 높을수록 구강건강상태가 양호함을 의미함

회귀분석 결과, 구강건강 요인 중 기능적 제한 이 전반적 건강상태에 유의한 정의 영향 $(\beta=.26$, $\mathrm{t}=3.13, \mathrm{p}<.01)$ 을 미치며, 나머지 동통·불편감, 심리 적 영향, 행동영향의 요인은 유의한 영향을 미치지 않는 것으로 나타나, 구강의 기능적 제한요인이 노 인의 전반적 건강상태에 영향을 미치는 가장 중요 한 요인임을 알 수 있었다. 변인이 가지는 설명력 은 $13 \%$ 로 나타났다.

\section{5. 구강건강이 사회활동에 미치는 영향}

구강건강이 노인의 사회활동에 미치는 영향을 알아보기 위하여 구강건강의 4 가지 하위요인을 독 립변인으로 투입하여 회귀분석을 시행하였으며 결 과는 <표 5 >와 같다.

회귀분석 결과, 구강건강 요인 중 심리적 영향 이 사회활동에 유의한 정의 영향 $(\beta=.22, \mathrm{t}=2.16$, $\mathrm{p}<.05)$ 을 미치며, 나머지 기능적 제한, 동통.불편 감, 행동영향의 요인은 유의한 영향을 미치지 않는 것으로 나타나, 구강건강이 나쁨으로 받는 심리적 영향요인이 노인의 사회활동에 영향을 미치는 가 장 중요한 요인임을 알 수 있었다. 변인이 가지는 설명력은 $10 \%$ 로 나타났다.

\section{IV. 결론 및 제언}

노인들의 건강에 직접적인 영향을 미치는 구강 건강과 관련한 삶의 질 지표인 노인구강건강평가 지수(Geriatric Oral Health Assessment Index, $\mathrm{GOHAI}$ 를 사용해 구강건강이 전반적인 건강상태 와 사회활동에 미치는 영향을 분석하여 노인의 구 강건강증진 프로그램 및 이에 관련된 정책개발을 위한 기초자료를 제공하고자 실시한 본 연구의 결 과는 다음과 같다.

조사대상자의 일반적인 특성으로는 성별의 경우 여자가 남자보다 많았고, 연령은 75 세 이하와 76세 이상이 비슷한 수준이며, 학력은 초등학교 졸업의 비율이 가장 높게 나타났다. 동거인은 혼자 살거 나 부부가 같이 산다는 비율이 비슷한 수준이며 직업은 조사대상자의 대부분이 없는 것으로 나타 났다. 소득원은 자녀라는 응답이 가장 많았으며, 소득정도는 보통이라는 응답이 가장 많았다.

일반적 사항에 따른 전반적 건강상태, 사회활동 및 구강건강 차이검증결과, 성별에 따라 전반적 건 강상태가 차이를 보였으나 구강건강은 유의한 차 이가 없었다. 이는 구강건강과 관련한 삶의 질 측 정에 있어 같은 도구를 사용한[14]의 연구와 구강 영향지수를 이용한[11]의 연구결과와 같았다. 그러 나 본 연구에서는 일반적 사항의 모든 항목에 따 
른 구강건강 삶의 질 점수에는 유의한 차이가 없 는 것으로 나타나 연령, 가구구성, 학력, 스트레스 정도에 따라 $\mathrm{GOHAI}$ 점수에 유의한 차이가 나타 난 [14]의 연구와는 다르게 나타났다.

상관분석을 통해 전반적 건강상태, 사회활동, 구 강건강의 관계를 알아본 결과에서 전반적 건강상 태는 구강건강의 하위요인 모두와 유의한 정적인 상관성 $(\mathrm{r}=.18 \sim 32, \mathrm{p}<.05)$ 을 가지고 있어 구강건강이 노인의 전반적 건강상태와 밀접한 관계가 있음을 알 수 있었고, 이는 전신적인 건강상태와 구강건강 관련 삶의 질이 유의한 상관성을 나타낸 [10]의 연 구결과와 유사하였다.

구강건강이 노인의 전반적 건강상태와 사회활동 에 미치는 영향을 알아보기 위하여 회귀분석을 실 시한 결과, 전반적 건강상태에는 구강건강 요인 중 기능적 제한이 유의한 정의 영향 $(\mathrm{p}<.01)$ 을 미치며, 사회활동에는 구강건강 요인 중 심리적 영향이 통 계학적으로 유의한 정의 영향( $\mathrm{p<.05)}$ 을 미쳤다. 회 귀분석 결과 변인이 가지는 설명력은 다소 낮게 나타났으나 노인의 건강에 구강건강이 영향을 미 치는 요인임은 서론의 여러 선행연구[12],[13]에서 도 나타난 바와 같이 분명하다고 볼 수 있으며, 구 강 건강 이외에도 선행연구에서 나타난 바와 같이 연령, 가구구성, 학력, 스트레스정도 등의 심리적인 변인들이 영향을 미치기 때문이라고 보여졌습니다.

기능적인 제한 요인이 전반적 건강상태와도 밀 접하게 연관되어 있다는 것은 노인들이 치아나 틀 니를 사용함에 따른 문제로 먹는 음식의 양이나 종류, 또는 저작능력이나 연하작용에 제한을 받게 됨으로써 섭식이 불편해지고 결국 식사의 양과 질 의 저하로 영양상의 불균형문제와 전신건강상태에 까지 영향을 미치게 되는 과정을 거치게 됨을 알 수 있다.

또한 노인의 사회활동에 심리적 영향요인이 가 장 유의했던 점은 본인이 인지하는 구강건강의 수 준 및 구강건강이 나쁨으로 받는 심각성이나 걱정,
또는 치아상실에 따른 발음 및 외관상 구강의 심 미적인 부분들이 총체적으로 대인관계 및 노인의 사회활동 참여에 제한 또는 적극성을 가지게 하는 주요한 원인이라 판단된다.

고령화 사회의 노인의 건강한 삶의 질 증진에 있어 구강건강은 무엇보다 중요하며 노인구강건강 향상을 위한 프로그램개발은 필수불가결하다 하겠 다. 과거 우리나라의 노인구강보건사업이 일부취약 계층노인의 최저 구강건강수준을 유지하기 위한 치료사업(의치보철사업)이 주된 내용이었다면 현재 는 과거에 비해 노인구강보건교육, 노인불소도포 등 지역사회별 노인구강건강향상을 위한 보다 다 양한 프로그램들이 추진되고 있지만 지역별 사업 추진의 적극성, 지원 및 적용대상범위에는 여전히 한계가 있다고 판단된다. 본 연구의 결과로 볼 때 전체적인 노인구강건강향상에 따른 삶의 질 수준 을 충족하기 위해서 향후 노인구강보건사업은 범 국가적인 차원에서 지역사회 전체 보건사업의 일 환으로 이루어지되 구강건강의 기본이 되는 기능 적인 요소에서부터 심리적인 영향까지 노인의 전 신건강 및 사회활동 및 참여를 고려한 처치 및 예 방 위주의 프로그램들이 다양하게 계획되고 지원 이 이루어져야 할 것이다.

본 연구는 조사대상이 일부지역에 한정되어 그 대표성에 한계를 지니며 앞으로 보다 광범위한 대 상으로의 연구가 필요하다고 생각되며, 또한 편의 표본추출에 의해 조사대상자를 선정하였기 때문에 연구결과를 일반화하기 어렵다. 또한 건강의 개념 이 포괄적이고 확대되는 현 시점에서 기존 문헌들 이 구강건강과 관련한 삶의 질을 평가하는 도구를 중심에 두고 인구사회학적인 특성과의 관계를 파 악하는데 그친 연구가 많아 본 연구와 비교, 평가 하는데 많은 어려움이 있었으며 향후에는 구강건 강과 관련한 삶의 질 평가지수에 보다 사회적.심 리적인 개념을 접목시킨 다양한 연구가 필요할 것 
으로 생각된다.

\section{참고문헌}

1. 구영경(2010), 노인의 구강위생행태와 주관적 구강 건강, 인제대학교 보건대학원 석사학위논문, pp.1.

2. 윤현숙, 김영법, 허소영(2006), 한국 노년학 연구에 대한 비판적 고찰, 한국노년학, $\mathrm{Vol} .26(3) ; 447-460$.

3. Rowe J. W. \& Kahn R. L.(1998), Successful aging, New York: Pantheon Books, pp.433-440.

4. 김 욱(2006), 경로당 이용 노인의 자아존중감과 영 향요인연구, 노인복지연구, Vol.32:271-293.

5. 나항진(2004), 삶의 질 향상을 위한 노인 여가의 역할에 관한 연구, 한국노년학, 24(1), pp.53-70.

6. 양민희(2009), 한국 노인의 사회활동과 주관적 삶 의 질, 이화여자대학교 석사학위논문, pp.1-3.

7. 김지화(2007), 구강보건이 전신건강과 삶의 질에 미치는 영향, 계명대학교대학원 박사학위논문, pp.1.

8. 신선정, 정세환(2011), 강원도 일부 노인에서의 노 인구강건강평가지수(GOHAI)의 타당도와 신뢰도, 대한구강보건학회지, $\mathrm{Vol} .35(2) ; 187-195$.

9. 장선희, 최미혜(2011), OHIP-14를 이용한 일부 요 양기관 노인들의 구강건강관련 삶의 질, 한국치위 생학회지, Vol.11(4);475-487.

10. 조영식, 임순연, 황혜림(2011), 50대 이상 장노년 층의 구강건강 관련 삶의 질과 구강 건강 결과의 관련성, 치위생과학회지, Vol.11(4);305-310.

11. 박정란, 김혜진(2011), 65세 이상 노인의 구강건 강관리요구도가 구강건강영향지수(OHIP-14)에 미 치는 영향, 한국치위생학회지, Vol.11(6);961-971.

12. 이명선, 임선아, 김진(2007), 노인의 구강건강 영 향지수에 영향을 미치는 요인, 조선대학교 통계연 구소 논문집, Vol.9(1);.19-31.

13. 박영애(2006), 노령인구에서 전신건강과 구강건강 과의 관련성 연구, 대구가톨릭대학교 보건과학대
학원 석사학위논문, pp.27-28.

14. 이민선, 신선정, 정세환(2011), 강원도 일부 농촌 지역 노인의 사회경제적 위치와 구강건강관련 삶 의 질과의 연관성, 한국치위생학회지, Vol.11(5); 707-715.

15. Atchison KA, Dolan TA.(1990), Development of the Geriatric Oral Health Assessment Index. J Dent Educ, Vol.54;680-7

16. 전예슬(2009), 가구유형에 따른 한국 노인의 건강 상태 비교연구, 이화여자대학교대학원 석사학위논 문, pp.44-45.

17. 윤명희(2005), 노년기 가치관과 사회활동과의 관 계, 한서대학교대학원 석사학위논문, p.31.

접수일자 2012년 2월 20일 심사일자 2012년 2월 22일

게재확정일자 2012년 2월 29일 